\title{
Weed Control and Selectivity to Post-Applied Herbicides in Eucalyptus
}

\author{
Allan Lopes Bacha ${ }^{1}$, Mariluce Pascoina Nepomuceno ${ }^{1}$, Willians César Carrega ${ }^{1}$, \\ Pedro de Figueiredo Rocha Barbosa Martins ${ }^{1} \&$ Pedro Luis da Costa Aguiar Alves ${ }^{1,2}$ \\ ${ }^{1}$ Weed Sciences Laboratory (LAPDA), Sao Paulo State University, UNESP/FCAV, Jaboticabal, SP, Brazil \\ ${ }^{2}$ Department of Biology Applied to Agriculture, Sao Paulo State University, UNESP/FCAV, Jaboticabal, SP, \\ Brazil \\ Correspondence: Allan Lopes Bacha, Weed Sciences Laboratory (LAPDA), Sao Paulo State University, \\ UNESP/FCAV, Via de Acesso Prof. Paulo Donato Castellane s/n, CEP 14884-900, Jaboticabal, SP, Brazil. Tel: \\ 55-16-3206-2620. E-mail: allan_lb@hotmail.com
}

Received: June 26, 2017

doi:10.5539/jas.v9n10p67
Accepted: July 30, $2017 \quad$ Online Published: September 15, 2017

URL: https://doi.org/10.5539/jas.v9n10p67

\begin{abstract}
The objective of this study was to evaluate the selectivity of fluazifop-p-butyl and haloxyfop-R methyl ester on Eucalyptus urograndis (clone GG100), as well as the use of fluazifop-p-butyl for control of Panicum maximum and Urochloa brizantha. Two experiments were conducted in 15-liter capacity pots, in a completely randomized design with four replications. The first experiment consisted of seven treatments, in which fluazifop-p-butyl and haloxyfop-R methyl ester were sprayed at 15, 30 and 37 days after planting (DAP) and a control plot without application. In the second experiment, the treatments consisted of a factorial $4 \times 2$ (four application periods and two weed species), in which three seedlings of $P$. maximum or $U$. brizantha were transplanted per pot. In both experiments, at $90 \mathrm{DAP}$, plant height, stem diameter, leaf area and total dry matter of eucalyptus were evaluated. In the second experiment, besides the morphological parameters, the percentage of weed control was evaluated. The data was submitted to analysis of variance by $\mathrm{F}$ test, and the means compared by Tukey test at the level of $5 \%$ of probability. Both herbicides did not cause visual effects of phytointoxication in eucalyptus, but haloxyfop$\mathrm{R}$ methyl ester was not selective to clone GG100 (E. urograndis). Fluazifop-p-butyl was selective to clone GG100, providing better control in the first application period (15 DAP) but only for P. maximum, which negatively affected the initial development of eucalyptus, while $U$. brizantha was not efficiently controlled with the usage of fluazifop-p-butyl.
\end{abstract}

Keywords: Eucalyptus urograndis, fluazifop-p-butyl, haloxyfop-R methyl ester, Panicum maximum, Urochloa brizantha

\section{Introduction}

In Brazil, eucalyptus cultivation has stood out amongst crops because of its high economic value. In recent years, the increase in planted area and productivity made this crop emerge as the main supplier of wood and pulp (Indústria Brasileira de Árvores [IBÁ], 2016). Data from IBÁ (2016) indicates that planted area in 2015 was about 5.6 million hectares with a productivity of $36 \mathrm{~m}^{3} \mathrm{ha}^{-1} \mathrm{year}^{-1}$. Thus, Brazil has the world's highest productive eucalyptus forests, which is mainly due to its genetic enhancing and adoption of ideal weed management (Stape, Binkley, Ryan, \& Gomes, 2004; Pereira, Yamauti, \& Alves, 2012).

Because of the eucalyptus expansion to areas previously occupied by pastures, weed species, including genus Urochloa sp. (Syn: Brachiaria sp.) and Panicum sp. are frequently infesting these areas. Even in low densities, these weeds can drastically affect the initial development of eucalyptus as they compete with the crop for water, light, space and nutrients (Toledo, Victória Filho, Alves, Pitelli, \& Lopes, 2003; Cruz, Alves, Karam, \& Ferraudo, 2010). Also, the interference imposed by weeds in forest areas is an important factor that may cause loss of productivity, and has been studied over the last decades in several countries through the world (Adams, Beadle, Mendham, \& Smethurst, 2003; Schaller, Schroth, Beer, \& Jiménez, 2003; Coll, Balandier, \& Picon-Cochard, 2004; Garau, Lemcoff, Ghersa, \& Beadle, 2008; Cruz et al., 2010).

The diversity of weed species in commercial forest areas is closely related to the history of the area, and the greatest weed interference is caused by plants with regrowth capacity, such as $U$. decumbens and $P$. maximum. Bacha, Pereira, Pires, Nepomuceno, and Alves (2016) reported that low density (3 plants $\left.\mathrm{m}^{-2}\right)$ of $U$. decumbens 
in the regrowth stage caused a reduction on the initial growth of eucalyptus up to $87 \%$ of total dry matter and $90 \%$ on leaf area. These results corroborate with Toledo, Victória Filho, Pitelli, Alves, and Lopes (2000), which found that eucalyptus plants cultivated for one year in coexistence with weeds show reductions of $71 \%$ on plant diameter and $68 \%$ on height, indicating the negative interference in the initial development when there is no proper weed management.

It is important to emphasize that the first year after the planting of eucalyptus seedlings is the period which plants are most susceptible to interference by biotic (e.g. presence of weeds) and abiotic factors (e.g. water or nutritional stress) (Pitelli \& Marchi, 1991; Florentine \& Fox, 2003; Garau, Ghersa, Lemcoff, \& Barañao, 2009), which may lead to productivity losses. This occurs because weed competition negatively influences several physiological variables of eucalyptus plants, such as water use efficiency, photosynthetic rate, stomatal conductance, and transpiration rates (Santos et al., 2015).

Regarding weed control, the chemical method provides many advantages, mainly economical, compared to mechanical methods, since it has greater agility with satisfactory results, especially in large areas, with a low value of labor costs. However, in order to obtain better use of chemical control, studies on herbicide selectivity are required (Gonçalves, José, Cavaliere, Martins, \& Velini, 2011).

According to Sistema de Agrotóxicos Fitossanitários (2017), the currently registered herbicides for post-emergence or pre-emergence weed control in eucalyptus are: chlorimuron-ethyl, carfentrazone-ethyl, sulfentrazone, saflufenacil, clomazone, oxyfluorfem, triclopyr-butotyl, indaziflam, Isoxaflutole and flumioxazin. Agostinetto et al. (2010) further states that glufosinate, glyphosate and sulfosate herbicides are used in the management of the pre-transplant or directed-jet area. In view of the above, it can be noted that there are few products registered for eucalyptus crop, and due to the increased cases of weeds resistant to herbicides (Heap, 2017), it is necessary to use molecules with different active principles.

Thus, the present work aimed to evaluate the selectivity of fluazifop-p-butyl and haloxyfop-R methyl ester herbicides in eucalyptus crop, and the efficacy of fluazifop-p-butyl for control of Panicum maximum and Urochloa brizantha.

\section{Materials and Methods}

\subsection{Experimental Area and Plant Materials}

Two experiments were conducted in a semi-controlled environment, during 90 days after planting (DAP) of eucalyptus seedlings, in pots with 15 liters capacity. As substratum, it was used a mixture of Eutrophic Dark-Red Oxisol and sand in a 1:1 ratio (v/v). The first experiment was conducted during January to April 2014; and the second experiment was performed during April to July 2014 (meteorological data on Table 1). In both experiments, all pots were irrigated daily until reaching field capacity.

In both experiments, the commercial Eucalyptus urograndis (E. grandis $\times$ E. urophylla-GG100 clone) seedlings, provided by Agriflora ${ }^{\circledR}$, were planted in the center of each pot. Each pot with eucalyptus seedling was considered an experimental unit. The plants used in both experiments had around 100 days of age, presented an average of $41 \mathrm{~cm}$ of height and $2.92 \mathrm{~mm}$ of stem diameter.

Table 1. Monthly meteorological data of Jaboticabal-SP region, Brazil, 2014

\begin{tabular}{lllllllll}
\hline Month & Pressure $(\mathrm{hPa})$ & $\operatorname{Tmax}\left({ }^{\circ} \mathrm{C}\right)$ & $\operatorname{Tmin}\left({ }^{\circ} \mathrm{C}\right)$ & $\operatorname{Tave}\left({ }^{\circ} \mathrm{C}\right)$ & $\mathrm{RH}(\%)$ & Precipitation $(\mathrm{mm})$ & $\mathrm{NRD}$ & Insolation $(\mathrm{h})$ \\
\hline Jan & 943.8 & 32.6 & 19.9 & 25.5 & 69.1 & 99.8 & 13 & 294.1 \\
Feb & 943.0 & 32.5 & 19.9 & 25.5 & 67.0 & 83.0 & 12 & 233.9 \\
Mar & 943.6 & 30.9 & 19.5 & 24.1 & 76.8 & 106.8 & 10 & 238.4 \\
Apr & 944.4 & 30.1 & 17.9 & 23.0 & 75.2 & 63.3 & 8 & 241.2 \\
May & 945.4 & 28.0 & 14.6 & 20.2 & 70.0 & 6.7 & 4 & 237.4 \\
Jun & 946.7 & 28.6 & 13.7 & 20.0 & 68.0 & 1.8 & 2 & 238.7 \\
Jul & 948.9 & 27.1 & 13.1 & 19.1 & 67.6 & 30.0 & 4 & 212.2 \\
\hline
\end{tabular}

Note. Pressure: atmospheric pressure; Tmax: average maximum temperature; Tmin: average minimum temperature; Tave: average temperature; RH: relative humidity of air; NRD: number of rainy days. 


\subsection{Treatments, Experimental Design and Herbicides Application}

The first experiment was installed in a completely randomized design with seven treatments and four replications (Table 2).

Table 2. Description of the treatments used in the first experiment

\begin{tabular}{llll}
\hline Treatment & Product & Dose $\left(\right.$ g a.e. or a.i. ha $\left.{ }^{-1}\right)$ & Application Period \\
\hline 1 & nontreated control & - & - \\
2 & fluazifop-p-butyl $^{1}$ & 187.5 & 15 DAP \\
3 & fluazifop-p-butyl & 187.5 & 30 DAP \\
4 & fluazifop-p-butyl & 250.0 & 37 DAP \\
5 & haloxyfop-R methyl ester & & 15 DAP \\
6 & haloxyfop-R methyl ester & 96.0 & 30 DAP \\
7 & haloxyfop-R methyl ester & 120.0 & 37 DAP
\end{tabular}

Note. ${ }^{1}$ fluazifop-p-butyl $=\left(\right.$ Fusilade $\left.250 \mathrm{EW}^{\mathbb{B}}\right) ;{ }^{2}$ haloxyfop-R methyl ester $=\left(\right.$ Verdict $\left.^{\mathbb{B}}\right) ;$ DAP $=$ Days after planting of eucalyptus.

For the second experiment, a previous sowing of P. maximum and U. brizantha, acquired from Agrocosmos ${ }^{\circledR}$, was carried out in trays with horticultural substratum. Twelve days after sowing, three seedlings were transplanted per pot (approximately 8 plants $\mathrm{m}^{-2}$ ), equidistantly, $10 \mathrm{~cm}$ from the center, where the eucalyptus was planted. The treatments consisted of a $4 \times 2$ factorial, corresponding to four application periods [0 DAP (without application), 15 DAP, 30 DAP and 37 DAP] and two weed species. A completely randomized design with four replicates was used, in which fluazifop-p-butyl (Fusilade $250 \mathrm{EW}^{\mathbb{B}}$ ) was sprayed at the same doses previously described for the respective periods (Table 2).

For both experiments, the application of the herbicides was performed using a $\mathrm{CO}_{2}$ pressurized costal sprayer, equipped with a TT 11002 regulated for a volume of $200 \mathrm{~L} \mathrm{ha}^{-1}$ at 2.2 bar tank pressure.

\subsection{Assessed Variables and Statistical Analysis}

In the first experiment, herbicide selectivity was evaluated in relation to the eucalyptus crop, through the scale that notes as 1 representing the absence of intoxication or any phytotoxical symptoms and notes as 9 the total death of plants (dryness of specimen, no chance of regrowth).

For the second experiment, the percentage of weed control was determined by a scale which notes 0 as the absence of control (specimens without any injury) and 100\% the death of weeds (dryness of specimen, no chance of regrowth).

For both experiments, at the end of the experimental period (90 DAP) was performed the evaluation of height and stem diameter of eucalyptus plants. Then, those were cut at base level and their leaves were removed for leaf area determination (LiCor, mod. Li 3100). Leaves and stems were dried in a forced air-circulation oven $\left( \pm 70{ }^{\circ} \mathrm{C}\right)$ for 96 hours to determine the dry matter mass.

The data collected was submitted to analysis of variance by $\mathrm{F}$ test and the means compared by Tukey test at 5\% of probability level. The software used for statistical analysis was AgroEstat (version 1.1.0.626).

\section{Results and Discussion}

\subsection{1 st Experiment: Selectivity of Graminicides to Eucalyptus}

During the experimental period, no visual symptoms of phytointoxication were observed for eucalyptus to any of the herbicides tested. However, it was possible to observe that at any period of application for haloxyfop-R methyl ester caused a decrease in the total dry matter at 90 DAP (Table 3). Also, smaller development was a result of second application period, in which the plants had 32\% lower dry matter than control (Table 3). For leaf area, it was observed that all treatments with haloxyfop-R methyl ester differed statistically from the control, but the same did not occur with plants treated with fluazifop-p-butyl, which shows that the molecule haloxyfop-R methyl ester is more phytotoxical to eucalyptus (E. urograndis-clone GG100) than fluazifop-p-butyl when applied in post-emergence. 
Table 3. Total dry matter (TDM), leaf area (LA), height and stem diameter of Eucalyptus urograndis (clone GG100) for three application periods of fluazifop-p-butyl and haloxyfop-R methyl

\begin{tabular}{lllll}
\hline Treatment & TDM $(\mathrm{g})$ & LA $\left(\mathrm{cm}^{2}\right)$ & Height $(\mathrm{cm})$ & Diameter $(\mathrm{mm})$ \\
\hline 1 - Control & $50.5 \mathrm{~A}$ & $4254.8 \mathrm{~A}$ & $68.5 \mathrm{~A}$ & $12.0 \mathrm{~A}$ \\
2 - Fluazifop ${ }^{1}$ at 15 DAP & $49.7 \mathrm{~A}$ & $3617.5 \mathrm{ABC}$ & $73.0 \mathrm{~A}$ & $11.0 \mathrm{~A}$ \\
3 - Fluazifop at 30 DAP & $49.5 \mathrm{~A}$ & $3930.6 \mathrm{AB}$ & $68.5 \mathrm{~A}$ & $12.2 \mathrm{~A}$ \\
4 - Fluazifop at 37 DAP & $49.2 \mathrm{~A}$ & $4201.0 \mathrm{~A}$ & $69.5 \mathrm{~A}$ & $11.5 \mathrm{~A}$ \\
5 - Haloxyfop ${ }^{2}$ at 15 DAP & $41.2 \mathrm{~B}$ & $3275.4 \mathrm{BC}$ & $70.0 \mathrm{~A}$ & $11.0 \mathrm{~A}$ \\
6 - Haloxyfop at 30 DAP & $34.7 \mathrm{C}$ & $2997.6 \mathrm{C}$ & $65.2 \mathrm{~A}$ & $10.5 \mathrm{~A}$ \\
7 - Haloxyfop at 37 DAP & $38.7 \mathrm{~B}$ & $3297.4 \mathrm{BC}$ & $67.2 \mathrm{~A}$ & $10.0 \mathrm{~A}$ \\
\hline F (Trat) & $68.7^{* *}$ & $8.84^{* *}$ & $1.98^{8 \mathrm{~ns}}$ & $2.36^{\text {ns }}$ \\
C.V. (\%) & 3.48 & 9.98 & 4.96 & 9.31 \\
\hline
\end{tabular}

Note. ${ }^{1}$ Fluazifop: fluazifop-p-butyl (Fusilade $250 \mathrm{EW}^{\mathrm{B}}$ ); ${ }^{2}$ Haloxyfop: haloxyfop-R methyl Ester $\left(\right.$ Verdict ${ }^{\mathrm{B}}$ ); Means followed by the same letter in the column do not differ significantly from each other at the level of $5 \%$ of probability by Tukey test; ${ }^{\mathrm{ns}}=$ Not significant by $\mathrm{F}$ test; ${ }^{* *}$ significant at the level of $1 \%$ of probability. C.V. $=$ Coefficient of variation. DAP $=$ Days after planting of eucalyptus.

There was no statistical difference between height and diameter treatments (Table 3). These results demonstrate that both molecules were less aggressive to eucalyptus compared to clomazone (Gamit $500^{\circledR}$ ), because at 35 days after application of the herbicide, Takahashi et al. (2009) reported a decrease up to $20 \%$ in plant height, using the commercial dose $\left(2 \mathrm{~L} \mathrm{ha}^{-1}\right)$. Regarding the diameter, Tuffi Santos, L. Ferreira, F. Ferreira, Duarte, and Tiburcio (2006), and Tiburcio, F. Ferreira, L. Ferreira, M. Machado, and A. Machado (2012) also found no significant difference for various herbicides evaluated, indicating that this characteristic is not affected in periods of evaluation equal to or lower than $90 \mathrm{DAP}$, probably because it is a perennial crop and presents a slower development.

Vidal, Kruse, Fleck, and Merotto Jr. (2000) observed negative effects of graminicides in dicotyledonous cultures. The authors concluded that high doses of fluazifop-p-butyl were not selective to melon and cucumber, reducing the dry matter of these plants, as observed for haloxyfop-R methyl in the present study. In general terms, dicotyledonous species do not present the homomeric plastid ACCase enzyme (Incledon \& Hall, 1997; Kukorelli, Reisinger, \& Pinke, 2013), which is the main focus of inhibition in this class of herbicides (aryloxyphenoxypropionic). Therefore, it is probable that the negative effect observed in these studies is due to the fact that the depolarization of the plasma membrane of the cells is greater than their repolarization capacity. Devine et al. (1993), working with the herbicides fenoxaprop and diclofop (also ACCase inhibitors), concluded that the effect of these products on membrane potential is an essential factor in their herbicidal action. This occurred when they observed that the resistant biotype of wild oat (Avena fatua L.) rapidly restored membrane potential while the susceptible remained depolarized.

In addition, it should be emphasized that within the same genus there are variations in responses to herbicides. At 45 days after the application of haloxyfop-R methyl in E. grandis and E. citriodora, there was no deleterious effect for any of the characteristics evaluated by W. Silva, J. Silva, Cardoso, and Barros (1994), while in the present study, at 90 DAP, some decreases in the dry matter and leaf area of E. urograndis (clone GG100) were observed.

\subsection{2nd Experiment: Control of Panicum Maximum and Urochloa Brizantha and Their Effects on Eucalyptus Growth}

For the second experiment, the only herbicide used was fluazifop-p-butyl due to the selectivity to eucalyptus crop reported in the first experiment.

Regarding the height and diameter of the eucalyptus evaluated at 90 DAP, no significant difference was observed, independently of weed species (Table 4). For the application period, higher values of diameter were verified at 15 DAP, which differed from the other treatments, which did not differ from each other. For the height of eucalyptus, the first application period again presented the highest value, matching the 37 DAP treatment, which had the highest dose of the herbicide $\left(250 \mathrm{~g}\right.$ i.a. $\left.\mathrm{ha}^{-1}\right)$. The second period was the only one that matched the control without application (Table 4). 
Table 4. Effect of application of fluazifop-p-butyl on the height, diameter, leaf area and total dry matter (TDM) of Eucalyptus urograndis (clone GG100) in coexistence with two weed species at 90 DAP

\begin{tabular}{lllll}
\hline Treatment & Height $(\mathrm{cm})$ & Diameter $(\mathrm{mm})$ & Leaf Area $\left(\mathrm{cm}^{2}\right)$ & TDM $(\mathrm{g})$ \\
\hline U. brizantha & 64.3 & 9.60 & $2633.5 \mathrm{~A}$ & $33.1 \mathrm{~A}$ \\
P. maximum & 62.1 & 9.47 & $1865.0 \mathrm{~B}$ & $23.9 \mathrm{~B}$ \\
\hline 15 DAP & $67.3 \mathrm{~A}$ & $11.3 \mathrm{~A}$ & $3958.0 \mathrm{~A}$ & $47.0 \mathrm{~A}$ \\
30 DAP & $61.8 \mathrm{BC}$ & $9.11 \mathrm{~B}$ & $1725.1 \mathrm{BC}$ & $22.1 \mathrm{C}$ \\
37 DAP & $65.1 \mathrm{AB}$ & $9.09 \mathrm{~B}$ & $1880.1 \mathrm{~B}$ & $27.4 \mathrm{~B}$ \\
Control & $60.0 \mathrm{C}$ & $8.55 \mathrm{~B}$ & $1433.8 \mathrm{C}$ & $17.3 \mathrm{D}$ \\
\hdashline F (Weed) & $1.99^{\mathrm{ns}}$ & $0.26^{\mathrm{ns}}$ & $68.4^{* *}$ & $120.2^{* *}$ \\
F (Application Period-AP) & $8.83^{* *}$ & $24.6^{* *}$ & $154.4^{* *}$ & $245.5^{* *}$ \\
F (Weed $\times$ AP) & $2.66^{\mathrm{ns}}$ & $1.78^{\mathrm{ns}}$ & $7.43^{* *}$ & $13.0^{* *}$ \\
C.V. $(\%)$ & 4.92 & 7.55 & 11.6 & 8.24 \\
\hline
\end{tabular}

Note. Means followed by the same letter in the column do not differ significantly from each other at the level of $5 \%$ of probability by Tukey test; ${ }^{\text {ns }}=$ Not significant by $\mathrm{F}$ test; ** significant at the level of $1 \%$ of probability. C.V. $=$ Coefficient of variation. DAP $=$ Days after planting of eucalyptus.

Regarding the significant interaction between weeds and period of application, the same pattern was observed in the results for leaf area and total dry matter (TDM) of eucalyptus, in which the plants coexisting with $P$. maximum presented lower values (Tables 5A and 5B), even though this weed species was better controlled (Tables 6 and 7). It is possible that the eucalyptus clone used is more sensitive to competition with $P$. maximum than with $U$. brizantha, because Cruz et al. (2010), analyzing the coexistence of $P$. maximum with five different eucalyptus clones, found that some clones showed a higher development compared to others, in which the most affected clones had 49\% less stem height and 53\% less dry matter, compared to the clone that most developed.

Table 5. Interaction between the factors application periods $\times$ weed species in the leaf area and total dry matter of eucalyptus plants submitted to different periods of application of fluazifop-p-butyl. At 90 days after planting (DAP)

\begin{tabular}{|c|c|c|c|}
\hline \multicolumn{4}{|c|}{ (A) Leaf Area $\left(\mathrm{cm}^{2}\right)$} \\
\hline Treatment & Urochloa brizantha & Panicum maximum & $\mathrm{F}$ \\
\hline 15 DAP & $4639.0 \mathrm{~A} \mathrm{a}$ & $3277.0 \mathrm{Ab}$ & $53.7 * *$ \\
\hline 30 DAP & $1814.2 \mathrm{C} \mathrm{a}$ & $1636.0 \mathrm{~B} \mathrm{a}$ & $0.92^{\mathrm{ns}}$ \\
\hline 37 DAP & $2355.5 \mathrm{~B} \mathrm{a}$ & 1404.7 B b & $26.2 * *$ \\
\hline Control & $1725.2 \mathrm{C} \mathrm{a}$ & $1142.5 \mathrm{~B} \mathrm{~b}$ & $9.85 * *$ \\
\hline $\mathrm{F}$ & $108.1 * *$ & $53.7 * *$ & - \\
\hline \multicolumn{4}{|c|}{ (B) Total Dry Matter (g) } \\
\hline Treatment & Urochloa brizantha & Panicum maximum & $\mathrm{F}$ \\
\hline 15 DAP & $53.3 \mathrm{~A} \mathrm{a}$ & $40.7 \mathrm{Ab}$ & $57.3 * *$ \\
\hline 30 DAP & $23.4 \mathrm{C} \mathrm{a}$ & $20.9 \mathrm{~B} \mathrm{a}$ & $2.23^{\mathrm{ns}}$ \\
\hline 37 DAP & $35.2 \mathrm{~B} \mathrm{a}$ & $19.7 \mathrm{~B} \mathrm{~b}$ & $87.6^{* *}$ \\
\hline Control & $20.3 \mathrm{C} \mathrm{a}$ & $14.4 \mathrm{C} \mathrm{b}$ & $12.2 * *$ \\
\hline $\mathrm{F}$ & $162.1 * *$ & $96.4^{* *}$ & - \\
\hline
\end{tabular}

Note. Means followed by the same uppercase letter in the column, and lowercase in the row, do not differ significantly from each other at the level of $5 \%$ of probability by Tukey test; ${ }^{\mathrm{ns}}=$ Not significant by $\mathrm{F}$ test; $* *$ significant at the level of $1 \%$ of probability.

For U. brizantha, the lowest leaf area found was in the control, which matched the 30 DAP, with a mean decrease of almost $62 \%$ (Table 5A). For TDM, the first period of application presented the higher value, with a difference of about 56\% compared to the second application (Table 5B). These results show that after 30 DAP the application of $250 \mathrm{~g}$ i.a. $\mathrm{ha}^{-1}$ should be preferred in comparison to $187.5 \mathrm{~g}$ i.a. $\mathrm{ha}^{-1}$, since the third period 
treatment (37 DAP) presented higher values of leaf area and TDM compared to the control and 30 DAP (Tables $5 \mathrm{~A}$ and $5 \mathrm{~B})$.

For weed control with fluazifop-p-butyl, it is noted that for all evaluations $P$. maximum was better controlled (Table 6). But analyzing the Tables $5 \mathrm{~A}$ and $5 \mathrm{~B}$, it is possible to observe that even being better controlled, this species affected the development of eucalyptus more drastically.

Table 6. Control percentages for weeds at 15, 21, 28, 35, 42 and 49 days after application (DAA) of fluazifop-p-butyl

\begin{tabular}{lllllll}
\hline Tratment & $15 \mathrm{DAA}$ & $21 \mathrm{DAA}$ & $28 \mathrm{DAA}$ & $35 \mathrm{DAA}$ & $42 \mathrm{DAA}$ & $49 \mathrm{DAA}$ \\
\hline $15 \mathrm{DAP}$ & $50.6 \mathrm{~A}$ & $65.6 \mathrm{~A}$ & $80.5 \mathrm{~A}$ & $80.5 \mathrm{~A}$ & $88.5 \mathrm{~A}$ & $89.7 \mathrm{~A}$ \\
$30 \mathrm{DAP}$ & $18.1 \mathrm{~B}$ & $23.7 \mathrm{~B}$ & $31.8 \mathrm{~B}$ & $28.7 \mathrm{~B}$ & $27.5 \mathrm{~B}$ & $30.6 \mathrm{~B}$ \\
37 DAP & $13.5 \mathrm{~B}$ & $31.2 \mathrm{~B}$ & $30.6 \mathrm{~B}$ & $29.3 \mathrm{~B}$ & $28.7 \mathrm{~B}$ & $36.8 \mathrm{~B}$ \\
\hline U. brizantha & $22.0 \mathrm{~B}$ & $35.0 \mathrm{~B}$ & $42.0 \mathrm{~B}$ & $39.5 \mathrm{~B}$ & $42.1 \mathrm{~B}$ & $47.9 \mathrm{~B}$ \\
P. maximum & $32.0 \mathrm{~A}$ & $45.4 \mathrm{~A}$ & $53.2 \mathrm{~A}$ & $52.8 \mathrm{~A}$ & $53.5 \mathrm{~A}$ & $56.9 \mathrm{~A}$ \\
\hline F (Application Period-AP) & $62.5^{* *}$ & $38.9^{* *}$ & $185.7^{* *}$ & $105.9^{* *}$ & $182.6^{* *}$ & $145.6^{* *}$ \\
F (Weed) & $11.0^{* *}$ & $6.35^{*}$ & $21.4^{* *}$ & $15.8^{* *}$ & $12.8^{* *}$ & $8.38^{* *}$ \\
F (AP $\times$ Weed) & $3.63^{*}$ & $0.01^{\mathrm{ns}}$ & $0.39^{\mathrm{ns}}$ & $0.68^{\mathrm{ns}}$ & $1.31^{\mathrm{ns}}$ & $0.86^{\mathrm{ns}}$ \\
C.V. $(\%)$ & 37.1 & 25.1 & 12.3 & 17.6 & 15.1 & 14.5
\end{tabular}

Note. Means followed by the same letter in the column do not differ significantly from each other at the level of $5 \%$ of probability by Tukey test; ${ }^{\mathrm{ns}}=$ Not significant by $\mathrm{F}$ test; $* *$ significant at the level of $1 \%$ of probability; * significant at the level of $5 \%$ of probability; C.V. $=$ Coefficient of variation. DAP $=$ Days after planting of eucalyptus.

The interaction between application period and weed control (Table 7) was observed only in the evaluation performed at 15 days after application (DAA) of the herbicide. It is possible to observe that, for both species, the best control was obtained in the first application period (15 DAP), in which P. maximum had better control, and the value was classified as "sufficient" according to the scale proposed by ALAM (1974). It should be emphasized that the effectiveness of the control depends, among other factors, on the weed species to be controlled. This can be observed in the work of Marques (2009), who found values of $87.4 \%$ of control for $U$. decumbens and $91.6 \%$ for $B$. plantaginea, 14 days after the application of $150 \mathrm{~g}$ i.a. ha ${ }^{-1}$ of fluazifop-p-butyl, when the plants had 3-4 tillers (23 days after emergence), equivalent stage to the first application period (15 DAP) of the present experiment (Table 6).

Table 7. Percentages of control for two weed species at 15 days after application (DAA) of fluazifop-p-butyl

\begin{tabular}{llll}
\hline Treatment & Urochloa brizantha & Panicum maximum & $\mathrm{F}$ \\
\hline $15 \mathrm{DAP}$ & $40.0 \mathrm{~A} \mathrm{~b}$ & $61.2 \mathrm{~A} \mathrm{a}$ & $16.67^{* *}$ \\
$30 \mathrm{DAP}$ & $15.0 \mathrm{~B} \mathrm{a}$ & $21.2 \mathrm{~B} \mathrm{a}$ & $1.44^{\mathrm{ns}}$ \\
$37 \mathrm{DAP}$ & $11.2 \mathrm{~B} \mathrm{a}$ & $13.7 \mathrm{~B} \mathrm{a}$ & $0.23^{\mathrm{ns}}$ \\
$\mathrm{F}$ & $18.03^{* *}$ & $48.15^{* *}$ & - \\
\hline
\end{tabular}

Note. Means followed by the same uppercase letter in the column, and lowercase in the row, do not differ significantly from each other at the level of $5 \%$ of probability by Tukey test; ${ }^{\text {ns }}=$ Not significant by $\mathrm{F}$ test; $* *$ significant at the level of $1 \%$ of probability; DAP = Days after planting of eucalyptus.

The herbicides that inhibites ACCase (i.e. fluazifop-p-butyl) act on the meristematic tissues of monocotyledonous plants, being translocated by the phloem after absorption by the leaves (Kukorelli et al., 2013). At the cellular level, these graminicides block the biosynthesis of fatty acids, making it impossible to form lipids and, consequently, affecting the integrity of the cell membrane. Thus, the extravasation of the intracellular contents occurs, leading to the death of the cells of the growth tissues (Délye, 2005; Kaundun, 2014).

However, besides the species, other factors also affect the efficient control of weeds, such as herbicide dose, environmental conditions during application, and weed development stage (Askew, Shaw, \& Street, 2000; 
Johnson \& Hoverstad, 2002). In this way, the later the application of the herbicide occurs, less tends to be the degree of control of the weeds, since they have a greater vegetative development and greater tolerance to herbicides. This fact can be observed when analyzing data from the third application period (37 DAP), in which there were no control values higher than $36.8 \%$ (Table 6). For the same stage of development, Marques (2009) found, for both $U$. decumbens and B. plantaginea, values lower than 29 and $37 \%$, respectively, at 17 DAA, corroborating the results found in the present study.

\section{Conclusion}

It is concluded that haloxyfop-R methyl ester was not selective to Eucalyptus urograndis clone GG100. Fluazifop-p-butyl was selective to clone GG100, providing better control at the first application period (15 days after plant transplant) only for Panicum maximum, which negatively affected the initial development of eucalyptus, whereas $U$. brizantha was not efficiently controlled with the use of fluazifop-p-butyl.

\section{Acknowledgements}

The authors thank all members of the Weed Sciences Laboratory (LAPDA) of Sao Paulo State University-UNESP/FCAV for the technical and financial support during the work.

\section{References}

Adams, P. R., Beadle, C. L., Mendham, N. J., \& Smethurst, P. J. (2003). The impact of timing and duration of grass control on the growth of a young Eucalyptus globules Labill. plantation. New Forests, 26, 147-165. https://doi.org/10.1023/A:1024490707175

Agostinetto, D., Tarouco, C. P., Markus, C., Oliveira, E., Silva, J. M. B. V., \& Tironi, S. P. (2010). Seletividade de genótipos de eucalipto a doses de herbicidas. Semina: Ciências Agrárias, 31, 585-598. https://doi.org/ 10.5433/1679-0359.2010v31n3p585

Askew, S. D., Shaw, D. R., \& Street, J. E. (2000). Graminicide application timing influences red rice (Oryza sativa) control and seedhead reduction in soybean (Glycine max). Weed Technology, 14, 176-181. https://doi.org/10.1614/0890-037X(2000)014[0176:GATIRR]2.0.CO;2

Asociación Latinoamericana de Malezas (ALAM). (1974). Recomendaciones sobre unificación de los sistemas de evaluación en ensayos de control de malezas. ALAM, 1, 35-38.

Bacha, A. L., Pereira, F. C. M., Pires, R. N., Nepomuceno, M. P., \& Alves, P. L. C. A. (2016). Interference of seeding and regrowth of signal grass weed (Urochloa decumbens) during the initial development of Eucalyptus urograndis $($ E. grandis $\times$ E. urophylla). Australian Journal of Crop Science, 10, 322-330. https://doi.org/10.21475/ajcs.2016.10.03.p6995

Coll, L., Balandier, P., \& Picon-Cochard, C. (2004). Morphological and physiological responses of beech (Fagus sylvatica) seedlings to grass-induced below ground competition. Tree Physiology, 24, 45-54. https://doi.org/ 10.1093/treephys/24.1.45

Cruz, M. B., Alves, P. L. C. A., Karam, D., \& Ferraudo, A. S. (2010). Capim-colonião e seus efeitos sobre o crescimento inicial de clones de Eucalyptus urograndis. Ciência Florestal, 20, 391-401. https://doi.org/ $10.5902 / 198050982054$

Délye, C. (2005). Weed resistance to acetyl coenzyme A carboxilase inhibitors: an update. Weed Science, 53, 728-746. https://doi.org/10.1614/WS-04-203R.1

Devine, M. D., Hall, J. C., Romano, M. L., Marles, M. A. S., Thomson, L. W., \& Shimabukuro, R. H. (1993). Diclofop and fenoxaprop resistance in wild oat is associated with an altered effect on the plasma membrane electrogenic potencial. Pesticide Biochemistry and Physiology, 45(3), 167-177. https://doi.org/10.1006/ pest.1993.1019

Florentine, S. K., \& Fox, J. E. D. (2003). Competition between Eucalyptus victrix seedlings and grass species. Ecological Research, 18, 25-39. https://doi.org/10.1046/j.1440-1703.2003.00531.x

Garau, A. M., Ghersa, C. M., Lemcoff, J. H., \& Barañao, J. J. (2009). Weeds in Eucalyptus globulus subsp. maidenii (F. Muell) establishment: Effects of competition on sapling growth and survivorship. New Forests, 37, 251-264. https://doi.org/10.1007/s11056-008-9121-8

Garau, A. M., Lemcoff, J. H., Ghersa, C. M., \& Beadle, C. L. (2008). Water stress tolerance in Eucalyptus globulus Labill. subsp. maidenii (F. Muell.) saplings induced by water restrictions imposed by weeds. Forest Ecology and Management, 255, 2811-2819. https://doi.org/10.1016/j.foreco.2008.01.054 
Gonçalves, K. S., José, A. R. S., Cavaliere, S. D., Martins, I. S. B., \& Velini, E. D. (2011). Seletividade de herbicidas aplicados em pós-emergência em pinhão manso (Jatropha curcas L.). Revista Brasileira de Herbicicidas, 10, 110-120. https://doi.org/10.7824/rbh.v10i2.105

Heap, I. (2017). The international survey of herbicide resistant weeds. Retrieved from http://www.weedscience.org

Incledon, B. J., \& Hall, C. J. (1997). Acetyl-coenzyme A carboxylase: Quaternary structure and inhibition by graminicidal herbicides. Pesticide Biochemistry and Physiology, 57, 255-271. https://oi.org/10.1006/ pest.1997.2279

Indústria Brasileira de Árvores (IBÁ). (2016). Relatório IBÁ 2016. Retrieved from http://iba.org/images/ shared/Biblioteca/IBA_RelatorioAnual2016_.pdf

Johnson, G. A., \& Hoverstad, T. R. (2002). Effect of row spacing and herbicide application timing on weed control and grain yield in corn (Zea mays). Weed Technology, 16, 548-553. https://doi.org/10.1614/0890-037X (2002)016[0548:EORSAH]2.0.CO;2

Kaundun, S. S. (2014). Resistance to acetyl-CoA carboxylase-inhibiting herbicides. Pest Management Science 70, 1405-1417. https://doi.org/10.1002/ps.3790

Kukorelli, G., Reisinger, P., \& Pinke, G. (2013). ACCase inhibitor herbicides-selectivity, weed resistance and fitness cost: A review. International Journal of Pest Management, 59, 165-173. https://doi.org/10.1080/ 09670874.2013 .821212

Marques, R. P. (2009). Características anatômicas foliares e controle químico em pós-emergência de Brachiaria decumbens e Brachiaria plantaginea (Master's thesis, Sao Paulo State University, UNESP, Faculdade de Ciências Agronômicas, Brazil). Retrieved from https://repositorio.unesp.br/handle/11449/86438

Pereira, F. C. M., Yamauti, M. S., \& Alves, P. L. C. A. (2012). Interaction between weed management and covering fertilization in the initial growth of Eucalyptus grandis $\times$ E. urophylla. Revista Arvore, 36, 941-949. https://doi.org/10.1590/S0100-67622012000500016

Pitelli, R. A., \& Marchi, S. R. (1991). Interferência das plantas invasoras nas áreas de reflorestamento. Seminário técnico sobre plantas daninhas e o uso de herbicidas em reflorestamento (Vol. 3, pp. 1-11). Belo Horizonte, Brazil.

Santos, M. V., Ferreira, E. A., Tuffi Santos, L. D., Fonseca, D. M., Aspiazú, I., Silva, D. V., ... Braga, R. R. (2015). Physiological aspects of acacia and eucalyptus in competition with Brachiaria. Australian Journal of Crop Science, 9, 210-214.

Schaller, M., Schroth, G., Beer, J., \& Jiménez, F. (2003). Root interactions between young Eucalyptus deglupta trees and competitive grass species in contour strips. Forest Ecology and Management, 179, 429-440. https://doi.org/10.1016/S0378-1127(02)00534-0

Silva, W., Silva, J. F., Cardoso, A. A., \& Barros, N. F. (1994). Tolerância de Eucalyptus spp. a diferentes herbicidas. Revista Árvore, 18, 287-300.

Sistema de Agrotóxicos Fitossanitários (AGROFIT). (2017). Agrofit consulta aberta. Retrieved from http://agrofit.agricultura.gov.br/agrofit_cons/principal_agrofit_cons

Stape, J. L., Binkley, D., Ryan, M. G., \& Gomes, A. N. (2004). Water use, water limitation, and water use efficiency in a eucalyptus plantation. Bosque, 25(2), 35-41. https://doi.org/10.4067/S0717-9200200400 0200004

Takahashi, E. N., Alves, P. L. C. A., Salgado, T. P., Farias, M. A., Silva, A. C., \& Biaggioni, B. T. (2009). Consequências da deriva de clomazone e sulfentrazone em clones de E. grandis $\times$ E. urophylla. Revista Árvore, 33, 675-683. https://doi.org/10.1590/S0100-67622009000400010

Tiburcio, R. A. S., Ferreira, F. A., Ferreira, L. R., Machado, M. S., \& Machado, A. F. L. (2012). Controle de plantas daninhas e seletividade do flumioxazin para eucalipto. Cerne, 18, 523-531. https://doi.org/10.1590/ S0104-77602012000400001

Toledo, R. E. B., Victória Filho, R., Alves, P. L. C. A., Pitelli, R. A., \& Lopes, M. A. F. (2003). Faixas de controle de plantas e seus reflexos no crescimento de plantas de eucalipto. Scientia Forestalis, 64, 78-92. 
Toledo, R. E. B., Victória Filho, R., Pitelli, R. A., Alves, P. L. C. A., \& Lopes, M. A. F. V. (2000). Efeitos de períodos de controle de plantas daninhas sobre o desenvolvimento inicial de plantas de eucalipto. Planta Daninha, 18, 395-404. https://doi.org/10.1590/S0100-83582000000300002

Tuffi Santos, L. D., Ferreira, L. R., Ferreira, F. A., Duarte, W. M., Tiburcio, R. A. S., \& Machado, A. F. L. I. (2006). Intoxicação de eucalipto submetido à deriva simulada de diferentes herbicidas. Planta Daninha, 24, 521-526. https://doi.org/10.1590/S0100-83582006000300014

Vidal, R. A., Kruse, N. D., Fleck, N. G., \& Merotto Jr., A. (2000). Seletividade do herbicida fluazifop-p-butil para cucurbitáceas. Planta Daninha, 18, 413-417. https://doi.org/10.1590/S0100-83582000000300004

\section{Copyrights}

Copyright for this article is retained by the author(s), with first publication rights granted to the journal.

This is an open-access article distributed under the terms and conditions of the Creative Commons Attribution license (http://creativecommons.org/licenses/by/4.0/). 